Article

\title{
Cloning and Characterization of Three Novel Enzymes Responsible for the Detoxification of Zearalenone
}

\author{
Yi Zhang ${ }^{1}$, Xiaomeng Liu ${ }^{2}$, Yunpeng Zhang ${ }^{2}$, Xiaolin Zhang ${ }^{2, *}$ and He Huang ${ }^{1, *}$ \\ 1 School of Pharmaceutical Sciences, Nanjing Tech University, Nanjing 211816, China; zhangyi_1012@126.com \\ 2 Beijing Key Laboratory of Nutrition \& Health and Food Safety, Nutrition and Health Research Institute, \\ COFCO, Beijing 102209, China; liuxiaomeng1@cofco.com (X.L.); zyp_cau@163.com (Y.Z.) \\ * Correspondence: zhangxiaolin1@cofco.com (X.Z.); huangh@njtech.edu.cn (H.H.)
}

check for updates

Citation: Zhang, Y.; Liu, X.; Zhang, Y.; Zhang, X.; Huang, H. Cloning and Characterization of Three Novel

Enzymes Responsible for the

Detoxification of Zearalenone. Toxins 2022, 14, 82. https://doi.org/ $10.3390 /$ toxins 14020082

Received: 16 November 2021 Accepted: 31 December 2021 Published: 21 January 2022

Publisher's Note: MDPI stays neutral with regard to jurisdictional claims in published maps and institutional affiliations.

Copyright: (C) 2022 by the authors. Licensee MDPI, Basel, Switzerland. This article is an open access article distributed under the terms and conditions of the Creative Commons Attribution (CC BY) license (https:// creativecommons.org/licenses/by/ $4.0 /)$.

\begin{abstract}
Zearalenone is a common mycotoxin contaminant in cereals that causes severe economic losses and serious risks to health of human and animals. Many strategies have been devised to degrade ZEN and keep food safe. The hydrolase ZHD101 from Clonostachys rosea, which catalyzes the hydrolytic degradation of ZEN, has been studied widely. In the current research, three new enzymes that have the capacity to detoxify ZEN were identified, namely CLA, EXO, and TRI, showing 61\%, $63 \%$, and $97 \%$ amino acids identities with ZHD101, respectively. Three coding genes was expressed as heterologous in Escherichia coli BL21. Through biochemical analysis, the purified recombinant CLA, EXO, TRI, and ZHD101 exhibited high activities of degrading ZEN with the specific activity of $114.8 \mathrm{U} / \mathrm{mg}, 459.0 \mathrm{U} / \mathrm{mg}, 239.8 \mathrm{U} / \mathrm{mg}$, and $242.8 \mathrm{U} / \mathrm{mg}$. The optimal temperatures of CLA, EXO, TRI, and ZHD101 were $40{ }^{\circ} \mathrm{C}, 40^{\circ} \mathrm{C}, 40{ }^{\circ} \mathrm{C}$, and $45^{\circ} \mathrm{C}$, and their optimum $\mathrm{pH}$ were $7.0,9.0,9.5$, and 9.0, respectively. Our study demonstrated that the novel enzymes CLA, EXO, and TRI possessed high ability to degrade ZEN from the model solutions and could be the promising candidates for ZEN detoxification in practical application.
\end{abstract}

Keywords: zearalenone; ZEN-degrading enzyme; ZHD101; protein expression

Key Contribution: Identified three new enzymes that could degrade ZEN efficiently and studied their properties compared to ZHD101.

\section{Introduction}

Zearalenone (ZEN) is a non-steroidal estrogenic mycotoxin biosynthesized by Fusarium strains, which was firstly isolated from moldy corn in 1962 [1] and widely contaminating musty corn, wheat, and other grains [2]. Since its structure is similar to estrogen, excessive intake of ZEN can cause anabolic activity and hyper-estrogenism in the reproductive organs of animals [3,4]; in addition, ZEN has also been known to show hepatotoxicity, hematotoxicity, immunotoxicity, and genotoxicity potential [5,6]. High incidences of ZEN was reported from different countries [7], including Europe, Asia, and Africa [8-11], resulting in huge loss of agriculture commodities [12]. Hence, many methods have been explored to reduce ZEN contamination [13].

Physical and chemical methods, including intensive heating, irradiation, adsorption, alkaline hydrolysis, and ozonation, were widely used to detoxify toxin-contaminated feedstocks [14-17]. However, ZEN is highly thermostable, insensitive to UV irradiation, and is not easy to destroy during feed processing $[18,19]$. As for chemical methods, only strong alkalis or oxidants could break its chemical structure [20]. Although these methods achieved reduction in ZEN concentration, there were many disadvantages, such as non-selectivity, destruction of nutrients, and introduction of pollution in the feeds [21,22]. In comparison, microbial strains [23-26] or isolated enzymes [27-29] are always used as the biological methods to degrade ZEN to non-estrogenic derivatives, among which ZEN-degrading 
enzymes were a more attractive alternative due to their safety, efficiency, and irreversibility. It was reported that ZEN-degrading enzyme ZHD101 isolated from Clonostachys rosea cleaved to the lactone ring of ZEN and yielded non-toxic alkylresorcinol product [30-33]. The encoding gene zhd101 has been expressed in different hosts successfully. In 2002, Takahashi-Ando et al. expressed zhd101 gene in Escherichia coli heterologously [30]. Then, the zhd101 gene was expressed in E. coli and Saccharomyces cerevisiae fused with an enhanced green fluorescence protein (EGFP) to visually monitor its detoxification activity [31]. The recombinant $E$. coli completely degraded $2 \mu \mathrm{g} / \mathrm{mL} Z \mathrm{ZNN}$ in $1 \mathrm{~h}$, while the recombinant S. cerevisiae only degraded $75 \%$ of ZEN in the medium in $4 \mathrm{~d}$. In 2005, Higa-Nishiyama et al. introduced the zhd101 gene into a model monocotyledon rice plant, and the protein extract from leaves showed the significant ability of degrading ZEN [32]. In addition, the zhd101 gene was expressed in Pichia pastoris GS115, and it only took $30 \mathrm{~min}$ to degrade $10 \mu \mathrm{g} / \mathrm{mL}$ ZEN by the purified enzyme [34]. In 2017, the zhd101 gene was introduced into Lactobacillus reuteri Pg4, and the transformed strain L. reuteri pNZ-zhd101 successfully expressed ZHD101 and acquired the capacity to degrade ZEN [35]. Until now, ZHD101 is still mostly studied for its high ZEN-degrading ability and mechanism.

E. coli is a commonly used host strain for heterologous protein expression considering its several prominent features, including fast cell growth in minimal media, low acetate production when grown in high levels of glucose, low protease abundance, and an amenability to high-density culture [36]. Extensive research has been investigated on expression of several highly homologous protein in different strains, including ZHD518 [37], ZENG [38], ZHD795 [39], and ZEN-jjm [40], which presented 65\%, 99\%, 62\%, and 99\% amino acid identities with ZHD101. All these existing ZEN-degrading lactonases possessed a relatively low optimum temperature and thermostability, which limits its use in the feed industry. Therefore, it is extremely important to excavate new genes encoding ZEN-degrading enzymes to further improve the degradation condition of ZEN.

In this study, three potential ZEN-degrading enzymes were screened based on the $\mathrm{k}$ protein sequences of reported ZHD101 in the NCBI, and the genes were expressed in E. coli. Results showed the purified enzymes could degrade ZEN efficiently, which will provide resources for the removal of ZEN in feed industry.

\section{Results}

\subsection{Selection of the ZEN-Degrading Enzymes}

To search for resources, the amino acid sequence of ZHD101 was compared with the database reserved in GenBank by protein BLAST. Indeed, 29 stains were identified (Figure 1), among which three proteins (GenBank accession number: XP_016613277.1, XP_013255140.1, AHG29544.1) shared 61.22\%, 62.88\%, and 97.35\% identities with ZHD101 (GenBank accession number: ALI16790.1), namely CLA, EXO, and TRI, respectively (Figure 2).

The sequences of the cla, exo, tri, and zhd101 gene from the Cladophialophora bantiana, Exophiala aquamarina, Trichoderma aggressivum, and C. rosea contained complete open reading frame (ORF). The length of sequences were $795 \mathrm{bp}, 792 \mathrm{bp}, 792 \mathrm{bp}$, and $792 \mathrm{bp}$, respectively. The overall G+C content of the genes were $41 \%, 42 \%, 42 \%$, and $46 \%$.

\subsection{Expression and Purification of the Four Proteins}

The genes encoding CLA, EXO, TRI, and ZHD101 proteins were cloned into expression vector pET28a (+) and confirmed successful construction by restriction endonuclease of BamHI and HindIII (Figure 3) and sequence analysis.

SDS-PAGE analysis revealed that the purified CLA, EXO, TRI, and ZHD101 migrated as single band with a molecular mass of about $29 \mathrm{kDa}$ (Figure 4), which was consistent with the theoretical molecular mass of $29.08 \mathrm{kDa}, 29.3 \mathrm{kDa}, 28.89 \mathrm{kDa}$, and $28.75 \mathrm{kDa}$, respectively. 


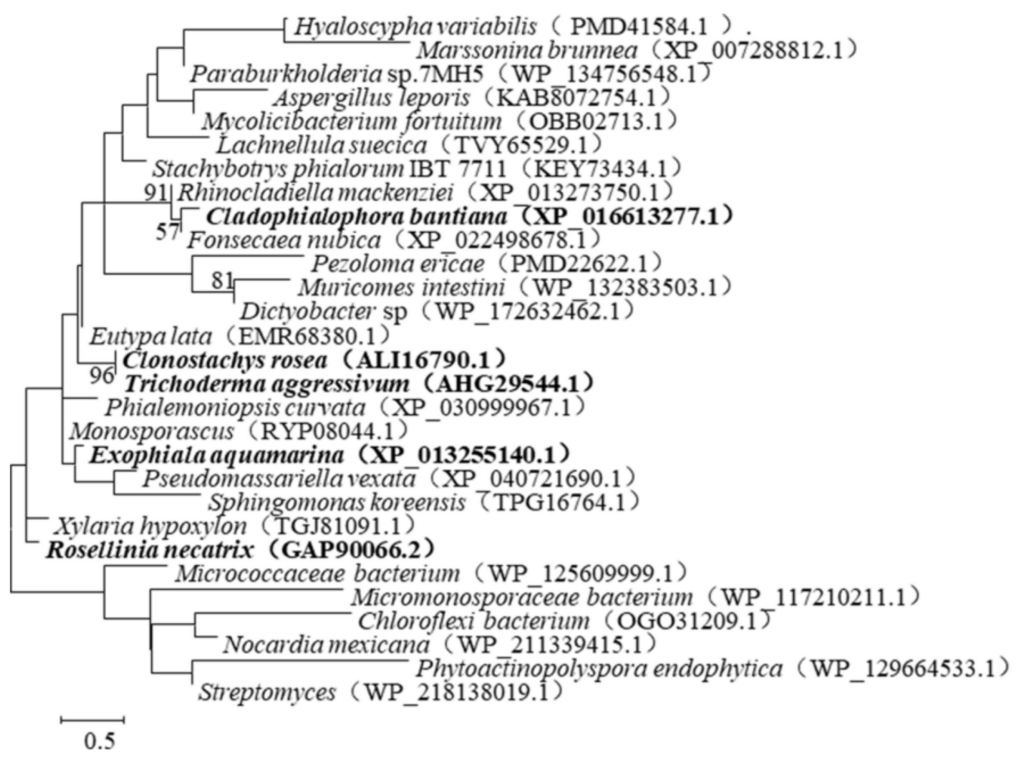

Figure 1. A phylogenetic tree was constructed based on the amino acid sequences of ZHD101 by means of neighbor-joining analysis. Bootstrap values ( $n=1000$ replicates) were reported as percentages.

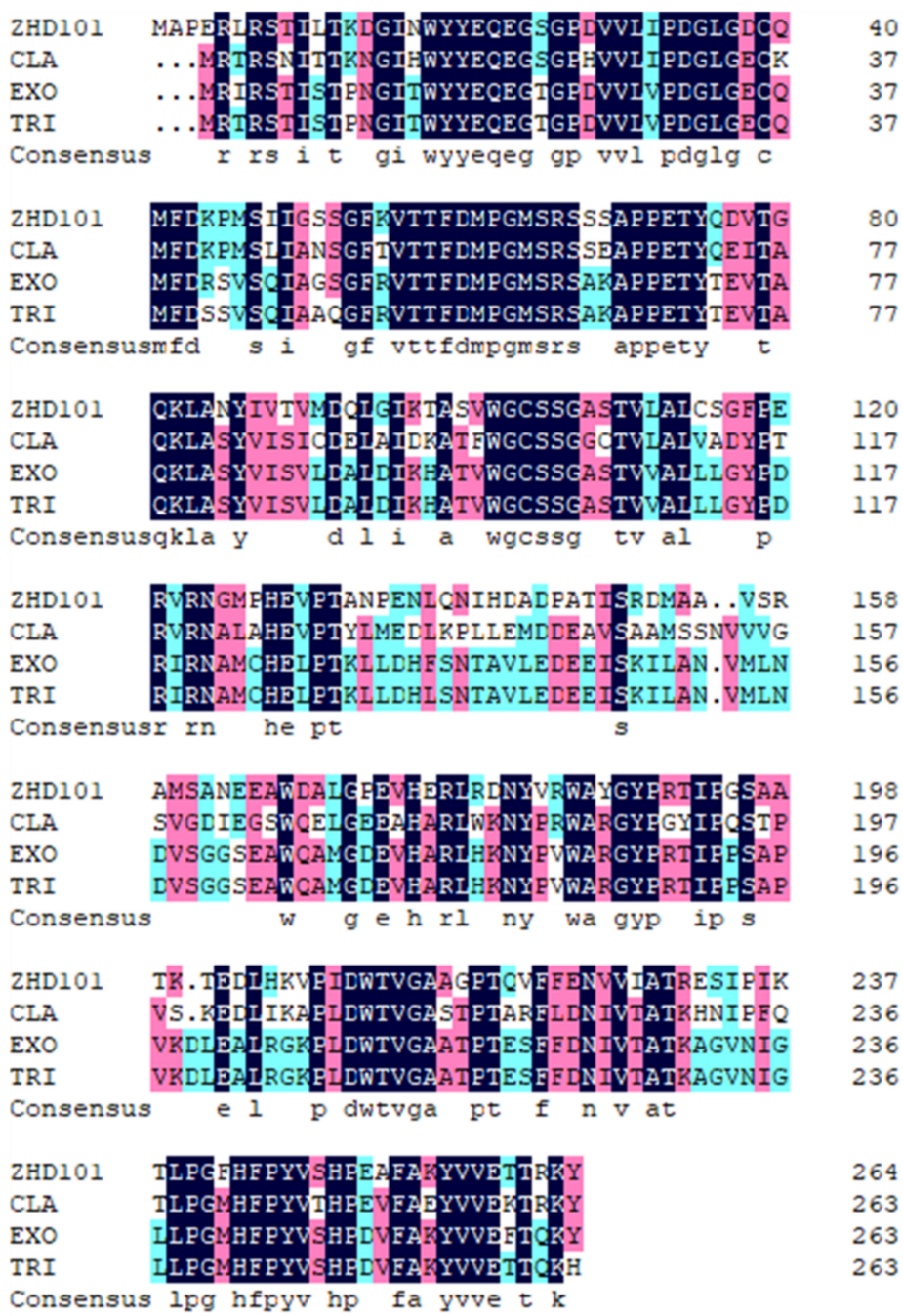

Figure 2. Amino acid sequence alignment of ZEN-degrading enzymes. 


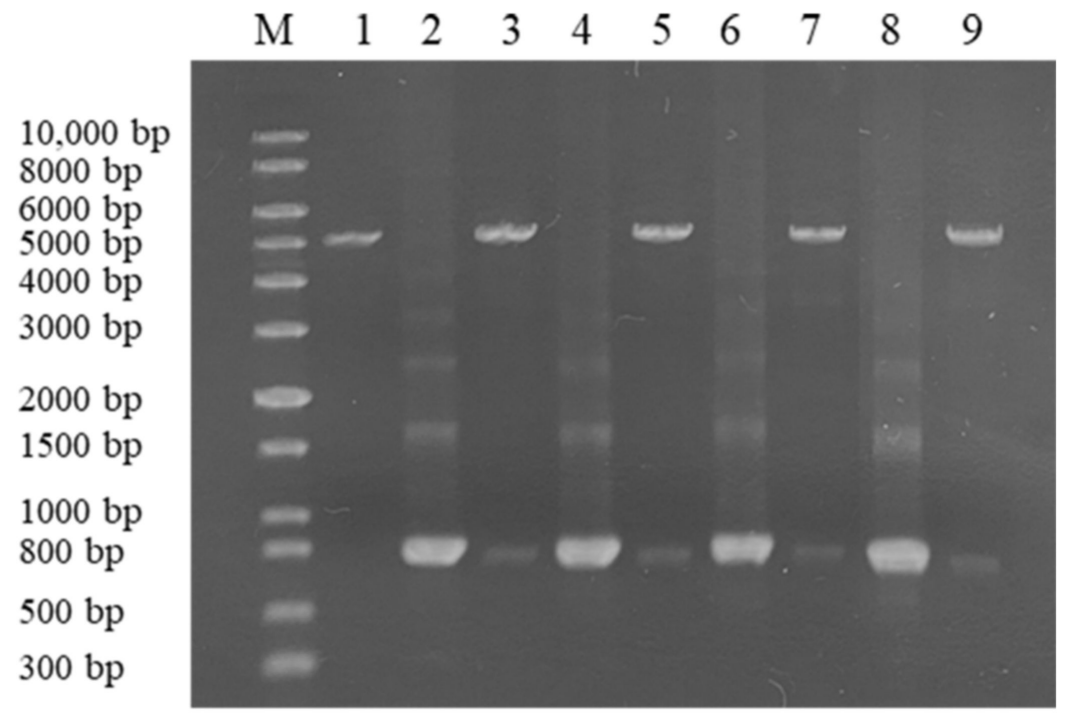

Figure 3. Electrophoresis analysis of expression plasmid. Lane M: $1 \mathrm{~kb}$ plus DNA marker; lane 1, pET28a (+); lane 2, 4, 6, 8, cla, exo, tri, zhd101; lane 3, 5, 7, 9, recombined plasmid pET28a (+)-cla, pET28a (+)-exo, pET28a (+)-tri, and pET28a (+)-zhd101 were digested by BamHI and HindIII.

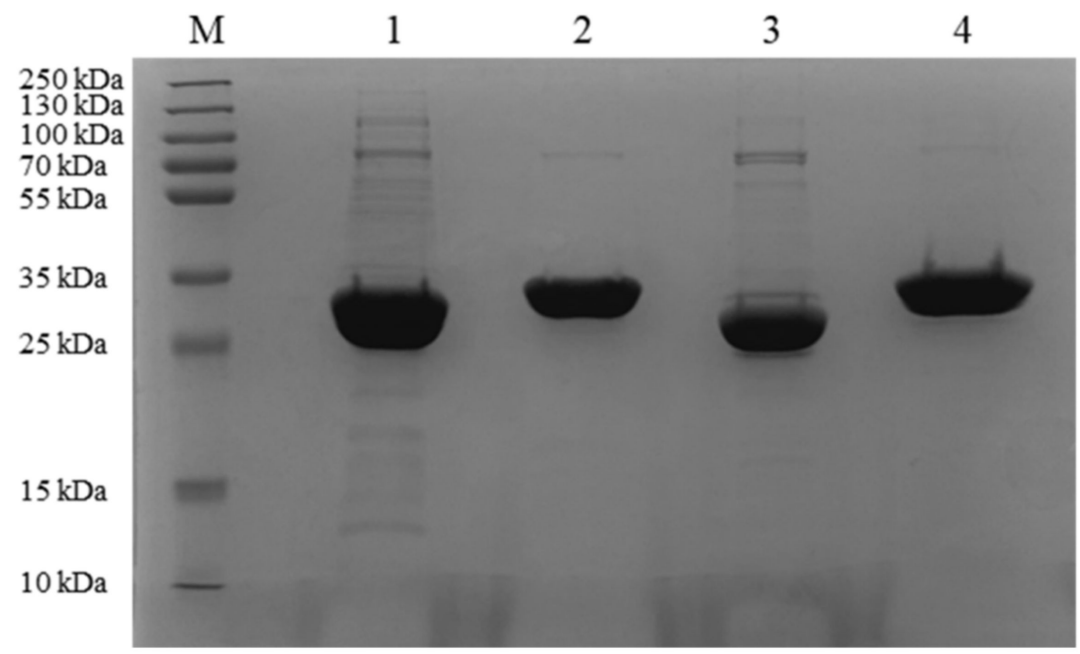

Figure 4. SDS-PAGE analysis of the recombinant protein. Lane M, prestained protein ladder (250, 130, $100,70,55,35,25,15$, and $10 \mathrm{kDa}$ ); lane 1, purified recombinant CLA; lane 2, purified recombinant EXO; lane 3, purified recombinant TRI; lane 4, purified recombinant ZHD101.

\subsection{Enzymatic Properties of the Four ZEN-Degrading Enzymes}

CLA showed high levels of activity at pH 7.0 to 7.5 (>90\%), while EXO, TRI, and ZHD101 showed high levels of degrading activity at pH 9.0 to 9.5 (>90\%) (Figure 5). The optimal $\mathrm{pH}$ for activity of four ZEN degrading-enzymes, including CLA, EXO, TRI, and ZHD101, was at $\mathrm{pH} 7.0,9.0,9.5$, and 9.0, respectively.

CLA, EXO, TRI, and ZHD101 showed optimal temperature degrading ZEN at $40{ }^{\circ} \mathrm{C}$, $40{ }^{\circ} \mathrm{C}, 40^{\circ} \mathrm{C}$, and $45^{\circ} \mathrm{C}$, and all of them performed more than $50 \%$ of the enzyme activity in the temperature range from $20^{\circ} \mathrm{C}$ to $45^{\circ} \mathrm{C}$. However, when temperature increased above $50{ }^{\circ} \mathrm{C}$, the relative activity decreased significantly (Figure 6A-D).

CLA, EXO, TRI, and ZHD101 were stable and retained at least $90 \%$ of activity after incubation at $40{ }^{\circ} \mathrm{C}$ for $10 \mathrm{~min}$. After being incubated at $50{ }^{\circ} \mathrm{C}$ for $5 \mathrm{~min}$, TRI and ZHD101 showed more than $50 \%$ of the maximum activity, but the activities substantially reduced above $50{ }^{\circ} \mathrm{C}$ (Figure 6E). 

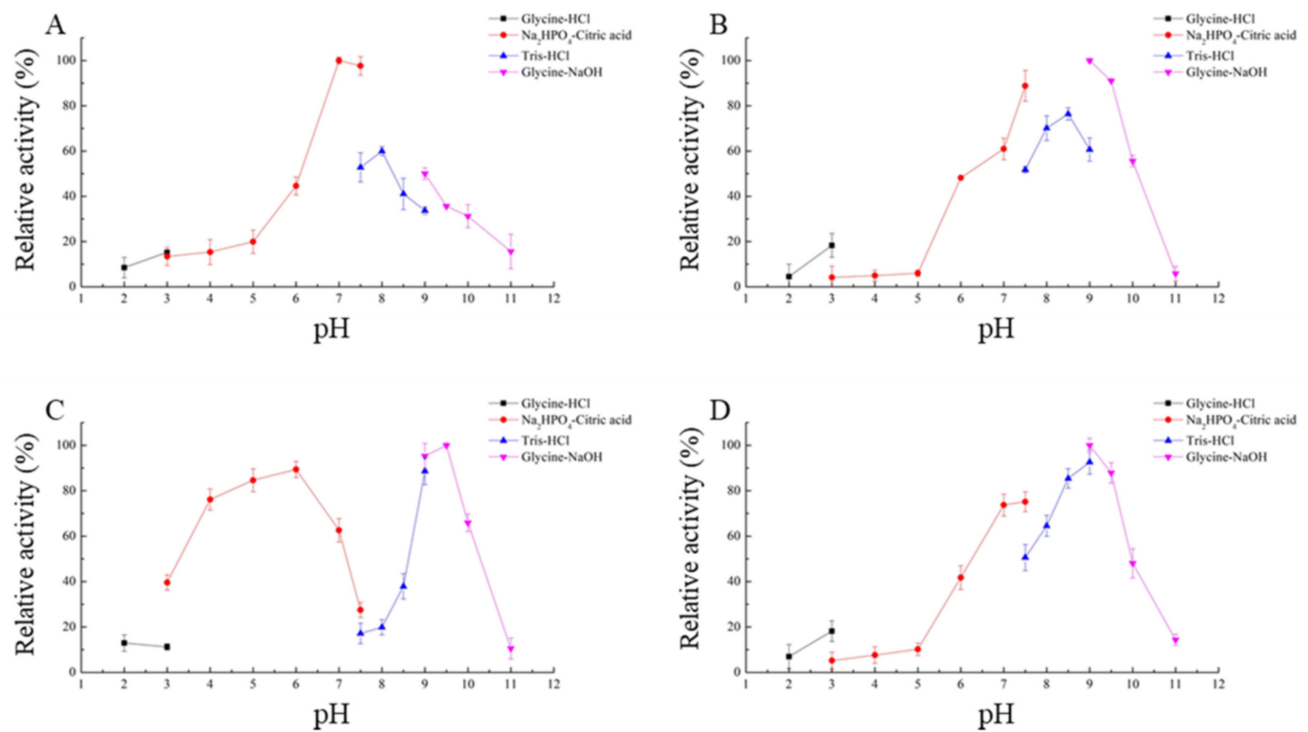

Figure 5. Effects of different $\mathrm{pH}$ on the enzyme activity of recombinant ZEN-degrading enzymes. (A) Effects of $\mathrm{pH}$ on CLA catalytic activity; (B) effects of $\mathrm{pH}$ on EXO catalytic activity; (C) effects of $\mathrm{pH}$ on TRI catalytic activity; (D) effects of $\mathrm{pH}$ on ZHD101 catalytic activity.
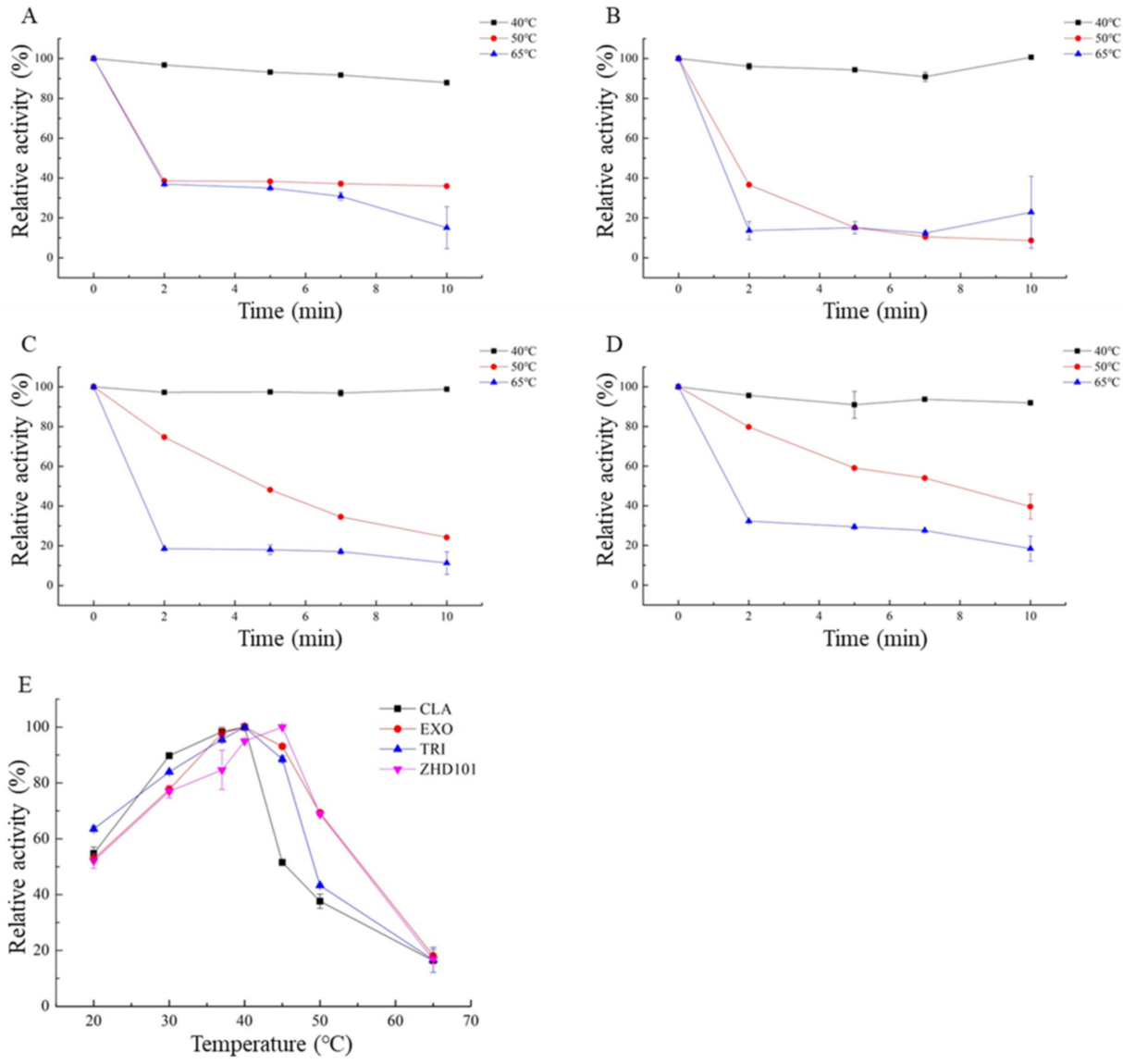

Figure 6. Effects of different temperature on the enzyme activity and stability of recombinant ZENdegrading enzymes. (A) Effects of temperature on CLA catalytic activity; (B) effects of temperature on EXO catalytic activity; (C) effects of temperature on TRI catalytic activity; (D) effects of temperature on ZHD101 catalytic activity; (E) thermostability of recombinant ZEN-degrading enzymes. 


\section{Discussion}

Numerous physical and chemical methods have been widely studied to prevent the growth of mycotoxigenic fungi and to detoxify ZEN-contaminated agricultural products over the past years [41]. However, most of them were not safe and useful in practice [42]. Biological decontamination exhibited an attractive alternative for minimizing the negative effects of mycotoxins because of its mild reaction conditions, high efficiency, and environmentally friendly nature [43]. The microorganisms degrading ZEN mainly involved two pathways, including the adsorption of the ZEN onto the walls of the microbial cells and degradation of the ZEN caused by biotransformation [44,45].

ZEN-degrading enzymes are able to convert ZEN into non-toxic or low-toxic products, and ZEN detoxification by ZHDCP and carboxypetidase enzyme produce H-ZEN ((E)2,4-dihydroxy-6-(10-hydroxy-6-oxo-1-undecen-1-yl)-benzoic acid) and D-ZEN ((E)-1-(3, 5dihydroxy-phenyl)-10-hydroxy-1-undecen-6-one), which were recognized as less estrogenic derivatives [46]. Viksoe-Nielsen and Soerensen discovered that the zearalenone in a feed product can be degraded into non-toxic substances by treating the feed product with laccases from Myceliophthora thermophila, Polyporus pinsitus, and Streptomyces coelicolor [47]. Effective detoxification can be achieved by deliberate introduction of purified enzymes during feed processing [48,49]. At present, the research of ZEN-degrading enzyme has become a hot spot, and it might be the significantly potential detoxification means for the future industrial application [44,48]. Lactono-hydrolase, such as ZHD101, ZHD518, ZENG, and ZENC, have been studied widely, and their capabilities to degrade ZEN and chemical structures have been reported $[31,37,38,50]$.

Here, the amino acid sequence of ZHD101 was compared by protein BLAST in the GenBank database, and three hypothetical proteins, CLA, EXO, and TRI, sharing $61.22 \%$, $62.88 \%$, and $97.35 \%$ homologies with ZHD101, were chosen and expressed in E. coli. The recombinant strains could remove ZEN from the model solutions rapidly and efficiently.

The biochemical analysis showed that the optimal temperature and $\mathrm{pH}$ of CLA, EXO, TRI, and ZHD101 were $40^{\circ} \mathrm{C}, 40^{\circ} \mathrm{C}, 40^{\circ} \mathrm{C}$, and $45^{\circ} \mathrm{C}$ and 7.0, 9.0, 9.5, and 9.0, respectively. It was found that the $\mathrm{pH}$ of the two potential ZEN-degrading enzymes EXO and TRI was identical with the ZHD of C. rosea IFO 7063 [30] and most other lactonases, which showed an alkaline optimal $\mathrm{pH}$ of generally 8.5 to $10.0[28,30,31,34]$, while the protein CLA exhibited the maximum activity at pH 7.0 in $50 \mathrm{mM} \mathrm{Na}_{2} \mathrm{HPO}_{4}$-citric acid buffer and decreased rapidly under alkaline conditions. This was significantly different from most of zearalenone lactono-hydrolases except for three proteins, namely ZHD518 [37], ZENC, and ZENG [38], whose optimal $\mathrm{pH}$ was 8.0, 8.0, and 7.0, respectively.

CLA had more than $85 \%$ enzyme activity (relative to maximum activity) at $30-40{ }^{\circ} \mathrm{C}$ and EXO, TRI, and ZHD101 remained over 75\%. The four ZEN-degrading enzymes showed a great amount loss of enzymatic activity beyond $65{ }^{\circ} \mathrm{C}$. It was interesting that four ZENdegrading enzymes still have more than $50 \%$ activity within $10 \mathrm{~min}$ of incubation even at $20{ }^{\circ} \mathrm{C}$, which is significant for industrial ZEN removal. Previous reports suggests that most of the ZEN-degrading lactonases, including RmZHD from Rhinocladiella mackenziei [28], ZHD101 from C. rosea [31], ZHD518 from R. mackenziei [37], ZENC from Neurospora crassa [50], and ZENG from G. roseum [38], displayed the maximum activities at a relatively low temperature ranging from $37^{\circ} \mathrm{C}$ to $45^{\circ} \mathrm{C}$. In addition, it was noticed that the CLA was homologous as expressed by Hui et al. [51]. According to their research, the same protein named CbZHD was expressed in E. coli, and CbZHD showed maximum activity at $\mathrm{pH} 8.0$ and $35^{\circ} \mathrm{C}$, which is different from our studies. It was speculated that the different reaction buffers might result in the different optimal conditions.

The present results demonstrated that CLA, EXO, TRI, and ZHD101 were promising enzymes that could be used for removing ZEN in the feed industries. It is noteworthy that the CLA even possess a higher enzyme activity than ZHD101 in a neutral $\mathrm{pH}$ condition. For industrial applications, large-scale production of the efficient ZEN-degrading enzyme and a more cost-effective expression system were urgent to be developed and employed. 


\section{Conclusions}

In conclusion, three novel ZEN-degrading enzymes named CLA, EXO, and TRI were cloned and produced using a heterologous $E$. coli expression system. It showed the optimal temperature and $\mathrm{pH}$ of CLA, EXO, and TRI were $40^{\circ} \mathrm{C}, 40^{\circ} \mathrm{C}$, and $40^{\circ} \mathrm{C}$ and 7.0, 9.0, and 9.5, respectively. The recombinant enzymes exhibited high detoxification of ZEN and could be used as potential candidates for commercial applications.

\section{Materials and Methods}

\subsection{Plasmids, Strains, Chemicals, and Medium}

E. coli JM109 was used as the cloning host strain. The plasmid pET28a (+) and E. coli BL21 (DE3) were used for gene expression. Luria-Bertani (LB) medium was prepared to culture the strains. Restriction enzymes ( $\mathrm{Ba} \mathrm{mHI}$ and HindIII), Ex Taq DNA polymerase, T4 DNA ligase, and other related enzymes were obtained from Takara (Dalian, China). Isopropyl- $\beta$-D-1-thiogalactopyranosid (IPTG) and kanamycin were purchased from Solarbio (Beijing, China). Zearalenone was bought from Pribolab (Qingdao, China) and dissolved in acetonitrile as a standard stock solution $(1 \mathrm{mg} / \mathrm{mL})$. Acetonitrile and methanol of HPLC grade were purchased from ANPEL laboratory Technologies (Shanghai, China).

\subsection{Cloning of the Four ZEN-Degrading Enzyme Genes and Expression in E. coli}

The sequences of ZEN-degrading enzyme encoding genes cla, exo, tri, and zhd101 were synthesized with addition of BamHI and HindIII restriction sites at both ends by Tsingke Company (Nanjing, China), then amplified by PCR with specific Primers (Table 1). The obtained PCR product was cloned into pET-28a (+) between the BamHI and HindIII restriction sites and fused in-frame with the $\alpha$-factor signal peptide. The recombinant plasmids were then transformed into E. coli BL21 (DE3) through electroporation for expression. Subsequently, the recombinant E. coli BL21 (DE3) strains were cultivated in $250 \mathrm{~mL}$ LB medium containing $50 \mu \mathrm{g} / \mathrm{mL}$ kanamycin at $37^{\circ} \mathrm{C}$ until $\mathrm{OD}_{600 \mathrm{~nm}}$ reached $0.6-0.8$, induced with $0.2 \mathrm{mM}$ IPTG shaken at $20^{\circ} \mathrm{C}$ for $6 \mathrm{~h}$. The cells were collected by centrifugation (6500 rpm, $5 \mathrm{~min}$ ) and stored at $-80^{\circ} \mathrm{C}$ before purification.

Table 1. Primers used in this study.

\begin{tabular}{|c|c|c|c|}
\hline Primer Name & Amplicon Gene & Sequences $\left(5^{\prime}-3^{\prime}\right)$ & Restriction Site \\
\hline CLA-F & \multirow[b]{2}{*}{ cla } & ATAGGATCCATGGCTCCAGAAAGATTGAG & BamHI \\
\hline CLA-R & & CGCAAGCTTTCACAAGTACTTTCTAGTAGTTT & HindIII \\
\hline EXO-F & \multirow{2}{*}{ exo } & ATAGGATCCATGAGAACCAGATCCAACAT & BamHI \\
\hline EXO-R & & CGCAAGCTTTCACAAGTACTTTCTAGTTTTTT & HindIII \\
\hline TRI-F & \multirow{2}{*}{ tri } & TCAGGATCCATGAGAATCAGATCCACCAT & BamHI \\
\hline TRI-R & & GGCAAGCTTTCACAAGTACTTCTGAGTAAACT & HindIII \\
\hline ZHD101-F & \multirow{2}{*}{ zhd101 } & ATAGGATCCATGAGAACGCGGAGCACGAT & BamHI \\
\hline ZHD101-R & & CGCAAGCTTCTACAGATGTTTCTGCGTCGTTT & HindIII \\
\hline
\end{tabular}

\subsection{Enzyme Purification and Molecular Mass Determination}

The cells pellets were resuspended in the lysis buffer $(50 \mathrm{mM}$ Tris- $\mathrm{HCl}, 0.5 \mathrm{M} \mathrm{NaCl}$, $\mathrm{pH}$ 7.5) and ultrasonically disrupted on ice for $15 \mathrm{~min}$ (ultrasonic $3 \mathrm{~s}$, pause $6 \mathrm{~s}$ ). The lysates were centrifuged at $4{ }^{\circ} \mathrm{C}, 12,000 \mathrm{rpm}$ for $15 \mathrm{~min}$ to remove cell debris. The supernatants were loaded onto the Ni-NTA column equilibrated with $50 \mathrm{mM}$ Tris- $\mathrm{HCl}$ buffer ( $\mathrm{pH}$ 8.0) and eluted with a gradient concentration of imidazole solution $(20-500 \mathrm{mM})$, then dialyzed in a buffer of $200 \mathrm{mM} \mathrm{NaCl}$ and $25 \mathrm{mM}$ Tris- $\mathrm{HCl}, \mathrm{pH}$ 7.5. The molecular mass of proteins was analyzed by $12 \%$ SDS-PAGE. The concentration of protein was determined with BCA Protein Assay Kit (Solarbio, China). 


\title{
5.4. Enzymatic Substrate Degrading Activity
}

The enzyme activity was characterized by substrate depletion. Each assay solution (500 $\mu \mathrm{L})$ contained $10 \mu \mathrm{L}$ substrate $(1 \mathrm{mg} / \mathrm{mL}$ ZEN in acetonitrile), $10 \mu \mathrm{L}$ diluted enzyme solution, and $480 \mu \mathrm{L}$ buffer. After incubation at the optimum temperature for $10 \mathrm{~min}, 500 \mu \mathrm{L}$ methanol was added to terminate the reaction. After filtration, the sample was analyzed using a Shimadzu LC-20AT HPLC system equipped with a Shimadzu RF-20A fluorescence detector. Aliquots of the tested solutions $(10 \mu \mathrm{L})$ were applied on a Agilent Eclipse XDBC18 column $(4.6 \mathrm{~mm} \times 150 \mathrm{~mm}, 5 \mu \mathrm{m})$ and eluted with a acetonitrile-water-methanol $\operatorname{mix}(46: 46: 8)$ at a rate of $1.0 \mathrm{~mL} / \mathrm{min}$. The column was kept at $40{ }^{\circ} \mathrm{C}$. The excitation and emission wavelengths were $274 \mathrm{~nm}$ and $440 \mathrm{~nm}$, respectively. Concentrations of ZEN were determined based on retention times and peak areas compared to ZEN standard stock solution. The peak area vs. ZEN concentration standard curve was plotted and was in very good correlation. One unit of ZEN-degrading enzyme activity was defined as the amount of enzyme required to degrade $1 \mu \mathrm{g}$ substrate per minute under standard assay conditions.

\subsection{Effects of Temperature and $p H$ on the Enzyme Activity and Stability}

To investigate the influence of $\mathrm{pH}$ on the four ZEN-degrading enzymes, enzymatic activity was determined in Glycine- $\mathrm{HCl}(50 \mathrm{mM}, \mathrm{pH} 2.0), \mathrm{Na}_{2} \mathrm{HPO}_{4}$-Citric acid (50 mM, $\mathrm{pH}$ 3.0-7.5), Tris- $\mathrm{HCl}(50 \mathrm{mM}, \mathrm{pH}$ 7.5-9.0), and Glycine- $\mathrm{NaOH}$ (50 mM, pH 9.0-11.0). The optimal temperature for activity of four ZEN-degrading enzymes was measured at $20^{\circ} \mathrm{C}$, $30{ }^{\circ} \mathrm{C}, 37^{\circ} \mathrm{C}, 40^{\circ} \mathrm{C}, 45^{\circ} \mathrm{C}, 50^{\circ} \mathrm{C}$, and $65^{\circ} \mathrm{C}$ at optimal $\mathrm{pH}$. The thermo-stability was assayed by pre-incubating the enzyme for $2 \mathrm{~min}, 5 \mathrm{~min}, 7 \mathrm{~min}$, and $10 \mathrm{~min}$ at $40^{\circ} \mathrm{C}, 50^{\circ} \mathrm{C}$, and $65{ }^{\circ} \mathrm{C}$, and then, the residual enzymatic activity was determined under optimal conditions. The untreated enzyme was used as the control.

\begin{abstract}
Author Contributions: Conceptualization, Y.Z. (Yunpeng Zhang) and X.L.; methodology, Y.Z. (Yunpeng Zhang), X.L., and Y.Z. (Yi Zhang); software, Y.Z. (Yunpeng Zhang), X.L., and Y.Z. (Yi Zhang); validation, Y.Z. (Yi Zhang) and X.L.; formal analysis, Y.Z. (Yunpeng Zhang) and Y.Z. (Yi Zhang); resources, X.L. and Y.Z. (Yi Zhang); data curation, X.Z.; writing-original draft preparation, Y.Z. (Yi Zhang) and X.L.; writing-review and editing, Y.Z. (Yi Zhang), X.L., and X.Z.; supervision, X.Z. and H.H.; project administration, X.Z.; funding acquisition, X.Z. All authors have read and agreed to the published version of the manuscript.
\end{abstract}

Funding: This research was funded by National Key Research and Development Program (2020YFC 1606804).

Institutional Review Board Statement: Not applicable.

Informed Consent Statement: Not applicable.

Data Availability Statement: The data that support the findings of this study are available from the corresponding author on reasonable request.

Conflicts of Interest: The authors declare no conflict of interest.

\section{References}

1. Stob, M.; Baldwin, R.S.; Tuite, J.; Andrews, F.N.; Gillette, K.G. Solation of an anabolic, uterotrophic compound from corn infected with Gibberella zeae. Nature 1962, 196, 1318. [CrossRef] [PubMed]

2. Alshannaq, A.; Yu, J.-H. Occurrence, toxicity, and analysis of major mycotoxins in food. Int. J. Environ. 2017, 14, 632. [CrossRef]

3. Kuiper-Goodman, T.; Scott, P.M.; Watanabe, H. Risk assessment of the mycotoxin zearalenone. Regul. Toxicol. Pharm 1987, 7, 253-306. [CrossRef]

4. Bulgaru, C.V.; Marin, D.E.; Pistol, G.C.; Taranu, I. Zearalenone and the immune response. Toxins 2021, 13, 248. [CrossRef] [PubMed]

5. Maaroufi, K.; Chekir, L.; Creppy, E.E.; Ellouz, F.; Bacha, H. Zearalenone induces modifications of haematological and biochemical parameters in rats. Toxicon 1996, 34, 535-540. [CrossRef]

6. Wang, Y.C.; Deng, J.L.; Xu, S.W.; Peng, X.; Zuo, Z.C.; Cui, H.M.; Wang, Y.; Ren, Z.H. Effects of zearalenone on il-2, il-6, and ifn- $\gamma$ mrna levels in the splenic lymphocytes of chickens. Sci. World J. 2012, 2012, 1-5. [CrossRef] [PubMed]

7. Scudamore, K.A.; Patel, S. Survey for aflatoxins, ochratoxin a, zearalenone and fumonisins in maize imported into the united kingdom. Food Addit. Contam. 2000, 17, 407-416. [CrossRef] [PubMed] 
8. Almeida, M.I.; Almeida, N.G.; Carvalho, K.L.; Gonçalves, G.A.A.; Silva, C.N.; Santos, E.A.; Garcia, J.C.; Vargas, E.A. Co-occurrence of aflatoxins b1, b2, g1and g2, ochratoxin a, zearalenone, deoxynivalenol, and citreoviridin in rice in brazil. Food Addit. Contam. Part A 2012, 29, 694-703. [CrossRef]

9. Pleadin, J.; Sokolović, M.; Perši, N.; Zadravec, M.; Jaki, V.; Vulić, A. Contamination of maize with deoxynivalenol and zearalenone in croatia. Food Control 2012, 28, 94-98. [CrossRef]

10. Rai, A.; Dixit, S.; Singh, S.P.; Gautam, N.K.; Das, M.; Tripathi, A. Presence of zearalenone in cereal grains and its exposure risk assessment in indian population. J. Food Sci. 2018, 83, 3126-3133. [CrossRef]

11. Zinedine, A.; Soriano, J.M.; Molto, J.C.; Man, J. Review on the toxicity, occurrence, metabolism, detoxification, regulations and intake of zearalenone: An oestrogenic mycotoxin. Food Chem. Toxicol. 2007, 45, 1-18. [CrossRef]

12. Ropejko, K.; Twarużek, M. Zearalenone and its metabolites-general overview, occurrence, and toxicity. Toxins 2021, 13, 35. [CrossRef] [PubMed]

13. Mahato, D.K.; Devi, S.; Pandhi, S.; Sharma, B.; Maurya, K.K.; Mishra, S.; Dhawan, K.; Selvakumar, R.; Kamle, M.; Mishra, A.K.; et al. Occurrence, impact on agriculture, human health, and management strategies of zearalenone in food and feed: A review. Toxins 2021, 13, 92. [CrossRef] [PubMed]

14. Kabak, B.; Dobson, A.D.W.; Var, I. Strategies to prevent mycotoxin contamination of food and animal feed: A review. Crit. Rev. Food Sci. Nutr. 2006, 46, 593-619. [CrossRef] [PubMed]

15. Calado, T.; Abrunhosa, L.; Cabo Verde, S.; Alté, L.; Venâncio, A.; Fernández-Cruz, M.L. Effect of gamma-radiation on zearalenonedegradation, cytotoxicity and estrogenicity. Foods 2020, 9, 1687. [CrossRef] [PubMed]

16. Xu, Y.; Wang, Y.; Ji, J.; Wu, H.; Pi, F.; Zhang, Y.; Sun, X. Chemical and toxicological alterations of zearalenone under ozone treatment. Food Addit. Contam. Part A 2018, 36, 163-174. [CrossRef] [PubMed]

17. Wang, G.; Lian, C.; Xi, Y.; Sun, Z.; Zheng, S. Evaluation of nonionic surfactant modified montmorillonite as mycotoxins adsorbent for aflatoxin b1 and zearalenone. J. Colloid Interface Sci. 2018, 518, 48-56. [CrossRef] [PubMed]

18. Kowalska, K.; Habrowska-Górczyńska, D.E.; Piastowska-Ciesielska, A.W. Zearalenone as an endocrine disruptor in humans Environ. Toxicol. Pharmacol. 2016, 48, 141-149. [CrossRef] [PubMed]

19. Luo, X.; Qi, L.; Liu, Y.; Wang, R.; Yang, D.; Li, K. Effects of electron beam irradiation on zearalenone and ochratoxin a in naturally contaminated corn and corn quality parameters. Toxins 2017, 9, 84. [CrossRef] [PubMed]

20. Mao, J.; He, B.; Zhang, L.; Li, P.; Zhang, Q.; Ding, X.; Zhang, W. A structure identification and toxicity assessment of the degradation products of aflatoxin b1 in peanut oil under uv irradiation. Toxins 2016, 8, 332. [CrossRef] [PubMed]

21. Ryu, D.; Hanna, M.A.; Bullerman, L.B. Stability of zearalenone during extrusion of corn grit. J. Food Prot. 1999, 62, 1482-1484. [CrossRef]

22. Bueno, D.J.; Marco, L.D.; Oliver, G.; Bardón, A. In vitro binding of zearalenone to different adsorbents. J. Food Prot. 2005, 68, 613-615. [CrossRef] [PubMed]

23. Kriszt, R.; Krifaton, C.; Szoboszlay, S.; Cserháti, M.; Kriszt, B.; Kukolya, J.; Czéh, A.; Fehér-Tóth, S.; Török, L.; Szőke, Z.; et al. A new zearalenone biodegradation strategy using non-pathogenic Rhodococcus pyridinivorans k408 strain. PLoS ONE 2012, 7, e43608. [CrossRef]

24. Wang, J.Q.; Yang, F.; Yang, P.L.; Liu, J.; Lv, Z.H. Microbial reduction of zearalenone by a new isolated Lysinibacillus sp. Zj-2016-1 World Mycotoxin J. 2018, 11, 571-578. [CrossRef]

25. Chen, S.-W.; Wang, H.-T.; Shih, W.-Y.; Ciou, Y.-A.; Chang, Y.-Y.; Ananda, L.; Wang, S.-Y.; Hsu, J.-T. Application of zearalenone (zen)-detoxifying bacillus in animal feed decontamination through fermentation. Toxins 2019, 11, 330. [CrossRef] [PubMed]

26. Kakeya, H.; Takahashi-Ando, N.; Klimura, M.; Onose, R. Biotransformation of the mycotoxin, zearalenone, to a non-estrogenic compound by a fungal strain of Clonostachys sp. Biosci. Biotechnol. Biochem. 2002, 66, 2723-2726. [CrossRef]

27. Banu, I.; Lupu, A.; Aprodu, I. Degradation of zearalenone by laccase enzyme. Sci. Study Res. 2013, 14, 79-84.

28. Zheng, Y.; Liu, W.; Chen, C.-C.; Hu, X.; Liu, W.; Ko, T.-P.; Tang, X.; Wei, H.; Huang, J.-W.; Guo, R.-T. Crystal structure of a mycoestrogen-detoxifying lactonase from Rhinocladiella mackenziei: Molecular insight into zhd substrate selectivity. ACS Catal. 2018, 8, 4294-4298. [CrossRef]

29. De Oliveira Garcia, S.; Sibaja, K.V.M.; Nogueira, W.V.; Feltrin, A.C.P.; Pinheiro, D.F.A.; Cerqueira, M.B.R.; Furlong, E.B.; GardaBuffon, J. Peroxidase as a simultaneous degradation agent of ochratoxin a and zearalenone applied to model solution and beer. Food Res. Int. 2020, 131, 109039. [CrossRef] [PubMed]

30. Takahashi-Ando, N.; Kimura, M.; Kakeya, H.; Osada, H.; Yamaguchi, I. A novel lactonohydrolase responsible for the detoxification of zearalenone: Enzyme purification and gene cloning. Biochem. J. 2002, 365, 1-6. [CrossRef]

31. Takahashi-Ando, N.; Ohsato, S.; Shibata, T.; Hamamoto, H.; Yamaguchi, I.; Kimura, M. Metabolism of zearalenone by genetically modified organisms expressing the detoxification gene from Clonostachys rosea. Appl. Environ. Microbiol. 2004, 70, 3239-3245. [CrossRef] [PubMed]

32. Higa-Nishiyama, A.; Takahashi-Ando, N.; Shimizu, T.; Kudo, T.; Yamaguchi, I.; Kimura, M. A model transgenic cereal plant with detoxification activity for the estrogenic mycotoxin zearalenone. Transgenic Res. 2005, 14, 713-717. [CrossRef]

33. Takahashi-Ando, N.; Tokai, T.; Hamamoto, H.; Yamaguchi, I.; Kimura, M. Efficient decontamination of zearalenone, the mycotoxin of cereal pathogen, by transgenic yeasts through the expression of a synthetic lactonohydrolase gene. Appl. Microbiol. Biotechnol. 2005, 67, 838-844. [CrossRef] 
34. Xiang, L.; Wang, Q.H.; Zhou, Y.L.; Yin, L.F.; Zhang, G.M.; Ma, Y.H. High-level expression of a zen-detoxifying gene by codon optimization and biobrick in Pichia pastoris. Microbiol. Res. 2016, 193, 48-56. [CrossRef] [PubMed]

35. Yang, W.C.; Hsu, T.C.; Cheng, K.C.; Liu, J.R. Expression of the clonostachys rosea lactonohydrolase gene by lactobacillus reuteri to increase its zearalenone-removing ability. Microb. Cell Fact. 2017, 16, 69. [CrossRef]

36. Yoon, S.H.; Jeong, H.; Kwon, S.K.; Kim, J.F. Genomics, Biological Features, and Biotechnological Applications of Escherichia Coli B: "Is B for Better?!"; Springer: Berlin/Heidelberg, Germany, 2009; pp. 1-17.

37. Wang, M.; Yin, L.; Hu, H.; Selvaraj, J.N.; Zhou, Y.; Zhang, G. Expression, functional analysis and mutation of a novel neutral zearalenone-degrading enzyme. Int. J. Biol. Macromol. 2018, 118, 1284-1292. [CrossRef]

38. Zhang, Z.; Xu, W.; Wu, H.; Zhang, W.; Mu, W. Identification of a potent enzyme for the detoxification of zearalenone. J. Agric. Food Chem. 2020, 68, 376-383. [CrossRef] [PubMed]

39. Chai, C.; Chang, X.; Wang, N. Cloning of zen-degrading enzyme zhd795 and study on degradation activity. J. Food Sci. Technol. 2018, 36, 28-32.

40. Cheng, B.; Shi, W.; Luo, J.; Peng, F.; Wan, C.; Wei, H. Cloning of zearalenone-degraded enzyme gene(zen-jjm) and its expression and activity analysis. J. Agric. Biotechnol. 2010, 18, 225-230.

41. Aiko, V.; Mehta, A. Occurrence, detection and detoxification of mycotoxins. J. Biosci. 2015, 40, 943-954. [CrossRef]

42. Grenier, B.; Loureiro-Bracarense, A.P.; Leslie, J.F.; Oswald, I.P. Physical and Chemical Methods for Mycotoxin Decontamination in Maize; Wiley: New York, NY, USA, 2014; pp. 116-127.

43. Wang, J.X.; Xie, Y.L. Review on microbial degradation of zearalenone and aflatoxins. Grain Oil Sci. Technol. 2020, 3, 117-125. [CrossRef]

44. Wang, N.; Wu, W.W.; Pan, J.W.; Long, M. Detoxification strategies for zearalenone using microorganisms: A review. Microorganisms 2019, 7, 208. [CrossRef] [PubMed]

45. Tinyiro, S.E.; Wokadala, C.; Xu, D.; Yao, W. Adsorption and degradation of zearalenone by bacillus strains. Folia Microbiol. 2011, 56, 321-327. [CrossRef] [PubMed]

46. Azam, M.S.; Yu, D.; Liu, N.; Wu, A. Degrading ochratoxin a and zearalenone mycotoxins using a multifunctional recombinant enzyme. Toxins 2019, 11, 301. [CrossRef] [PubMed]

47. Viksoe-Nielsen, A.; Soerensen, B.H. Process for Degrading Zearalenone in a Feed Product Employing Lacasse. European Patent WO 2009/077447 A1, PCT/EP2008/067409, 25 June 2009.

48. Karlovsky, P.; Suman, M.; Berthiller, F.; De Meester, J.; Eisenbrand, G.; Perrin, I.; Oswald, I.P.; Speijers, G.; Chiodini, A.; Recker, T.; et al. Impact of food processing and detoxification treatments on mycotoxin contamination. Mycotoxin Res. 2016, 32, 179-205. [CrossRef] [PubMed]

49. Yu, Y.; Wu, H.; Tang, Y.; Qiu, L. Cloning, expression of a peroxiredoxin gene from acinetobacter sp. SM04 and characterization of its recombinant protein for zearalenone detoxification. Microbiol. Res. 2012, 167, 121-126. [CrossRef]

50. Bi, K.; Zhang, W.; Xiao, Z.; Zhang, D. Characterization, expression and application of a zearalenone degrading enzyme from Neurospora crassa. AMB Express 2018, 8, 194. [CrossRef]

51. Hui, R.; Hu, X.; Liu, W.; Liu, W.; Zheng, Y. Characterization and crystal structure of a novel zearalenone hydrolase from Cladophialophora bantiana. Acta Crystallogr. F 2017, 73, 515-519. [CrossRef] [PubMed] 